\title{
Segregation of Presynaptic Inputs on an Identified Target Neuron in vitro: Structural Remodeling Visualized over Time
}

\author{
Michael Bank and Samuel Schacher \\ Center for Neurobiology and Behavior, Columbia University, College of Physicians and Surgeons, New York, New York \\ 10032
}

\begin{abstract}
Sensory cells of Aplysia form chemical synapses with the motor cell L7 in culture. Under certain conditions, sensory cells will also form electrical connections with each other. Sites of chemical synaptic interaction between the sensory cells and $L 7$ are located at varicosities along sensory cell processes that overlie the main axons of L7, since these structures have been shown ultrastructurally to contain active zones. Previous studies have suggested that the distribution of sensory cell varicosities can be restricted to exclusive regions of the motor cell by the presence of other sensory cells. We wished to investigate (1) how this segregated pattern is generated over time and (2) whether electrical coupling between sensory cells has an effect on this segregated pattern. Using fluorescent dye injection and lowlight video microscopy, we visualized the distribution of varicosities for each of two sensory cells growing on L7. In cases in which sensory cells are not electrically coupled, the varicosities from these two cells are spatially segregated on the target after $\mathbf{4} \mathbf{d}$ in culture but not after $2 \mathrm{~d}$ in culture. Examination of the varicosity distribution of the same sensory cells on the second and third day of growth indicated both an increased rate in the elimination of varicosities from previously occupied areas and a restriction of varicosity formation in new areas of the target when a second sensory cell is present. For sensory cells that are electrically coupled, varicosities from these cells were not spatially segregated on the target even after $4 \mathrm{~d}$ in culture. These observations in vitro suggest that segregation of synaptic inputs by Aplysia sensory cells, which show little spontaneous activity of action potentials, can emerge over time via a process that includes both the elimination of existing sensory varicosities and the restriction of new varicosity formation. Our results also suggest that electrical connections between presynaptic cells can disrupt the segregation of their varicosities on a target, resulting in significant changes in the developing connectivity.
\end{abstract}

Segregation of synaptic inputs within a target region is a widespread phenomenon seen in the CNS and PNS of vertebrates and invertebrates (Purves and Lichtman, 1985). A mature seg-

\footnotetext{
Received Oct. 1, 1991; revised Jan. 30, 1992; accepted Mar. 10, 1992.

This work was supported by NIH Grant NS27541 and NSF Grant BNS 9021612 We thank Dr. I. Kupfermann, Dr. N. Dale, and D. Hawver for their helpful comments, and F. Wu and R. Woolley for their technical assistance.

Correspondence should be addressed to Samuel Schacher, Ph.D., Center for Neurobiology and Behavior, Columbia University, College of Physicians and Surgeons, 722 West 168th Street, New York, NY 10032.

Copyright (C) 1992 Society for Neuroscience $0270-6474 / 92 / 122960-13 \$ 05.00 / 0$
}

regated pattern of connections appears to emerge from an immature state in which presynaptic inputs initially overlap. At the neuromuscular junction of skeletal muscle, during both development (Tello, 1917; Boeke, 1932; Redfern, 1970; Bennett and Pettigrew, 1974) and reinnervation (Tate and Westerman, 1973; McArdle, 1975; Rich and Lichtman, 1989), the final pattern of a single axon occupying each endplate arises from an earlier situation in which multiple inputs converge on these structures. Similarly, the mature segregated projection of inputs from each eye into ocular dominance columns in laycr four of the visual cortex evolves from an earlier pattern in which inputs from both eyes to this region extensively overlap (Hubel et al., 1977).

Competition among afferents for postsynaptic space or a trophic factor released by the postsynaptic cell is thought to play a role in the development of segregation of different presynaptic inputs to different target areas (Hubel et al., 1977; Purves, 1977; Purves and Lichtman, 1985; Rakic, 1986). Evidence for a role of competitive interactions in segregative processes comes from experiments in which a target receiving multiple inputs is partially deinnervated. In several systems, this procedure leads to an abolition of regional constraints manifested either as spreading of the remaining inputs throughout the target or as a shifting of these inputs toward newly deinnervated areas (Rakic, 1981; Blackshaw et al., 1982; Murphy and Lemere, 1984; Murphy, 1986; Gu and Muller, 1990). The competitive process that leads to segregation of inputs may depend on convergent synaptic interactions that are later eliminated (Shatz and Kirkwood, 1984; Shatz, 1990a,b).

Competition has been shown to be modulated by both level and pattern of activity in several systems (Purves and Lichtman, 1985; Shatz, 1990a). Blockade of activity with TTX leads to a persistence or reemergence of an unsegregated pattern of connections in target structures in which inputs are normally segregated (Meyer, 1982; Reh and Constantine-Paton, 1985; Stryker and Harris, 1986; Shatz and Stryker, 1988). The level of activity in a developing system is not the sole parameter for mediating competition (Wiesel and Hubel, 1965). The pattern of activity also has been shown to be an important determinant of the degree to which different inputs compete (Hubel and Wiesel, 1965; Van Sluyters and Levitt, 1980; Stryker and Strickland, 1984; Purves and Lichtman, 1985).

We want to study the process of competition in a simple in vitro system of identified Aplysia neurons. Such a minimalist system offers easy identification of synaptic partners, a controlled, static environment good for pharmacological manipulations, and easy access to individual cells for electrophysiological recording and stimulation or intracellular dye injection. In 
vitro systems have already been employed to study the role of presynaptic activity in synaptic competition (Nelson et al., 1989; Lo and Poo, 1991). In addition, a segregative phenomenon has been described in such a simple system. The sensory cells of Aplysia when cocultured with the motor cell L7 tend to segregate their processes to different areas of this synaptic target (Glanzman et al., 1991). This segregation occurs despite the fact that the presynaptic sensory cells both in vivo and in vitro, and the motor cell target in culture, lack spontaneous spike activity. We have investigated whether or not the segregative process in this system shows similarities to other segregative processes involving competition. In addition, we have studied how the relationship between presynaptic cells influences the rigorousness of the segregation of their inputs onto a common target. We find that the segregative process in this in vitro system is similar to those described previously in that a mature pattern appears to emerge from an earlier state in which inputs extensively overlap and that elimination of synaptic inputs may play a role in this process. In addition, we find that electrical coupling between presynaptic cells in this system interferes with the segregation of their inputs to different regions of a common target and leads to an increase in the efficacy of the developing connections.

\section{Materials and Methods}

Cell culture. Sensory cells isolated from the pleural ganglia dissected from adult animals (80-100 gm; Marinus, Long Beach, CA) were cocultured with the motor cell L7 isolated from the abdominal ganglion of juvenile animals (1-3 gm; Howard Hughes Medical Institute, Miami, FL) as described previously (Schacher, 1985; Rayport and Schacher, 1986; Glanzman et al., 1989). Each culture contained one or two sensory cells plated with a single L7 and was maintained in culture medium for 2-4 d as previously described (Schacher and Proshansky, 1983; Schacher et al., 1990). When two sensory cells were used, they were plated with their axon stumps converging on the same region of L7's main axons in order to maximize competitive interactions (Fig. 1). L7's main axons were a minimum of $270 \mu \mathrm{m}$ in length in all cultures used.

Electrophysiology. The stimulation and recording techniques have been described (Dale et al., 1988; Montarolo et al., 1988; Schacher et al., 1990). The motor cell L7 was held at a potential of $30 \mathrm{mV}$ below resting level (range, -37 to $-63 \mathrm{mV}$ ), and excitatory postsynaptic potentials (EPSPs) were evoked in L7 by stimulating each sensory cell in turn with a brief $(0.5-1 \mathrm{msec})$ depolarizing pulse from an extracellular electrode placed near each sensory cell soma. Cultures with EPSPs less than $4 \mathrm{mV}$ were discarded to ensure that each sensory cell contributed at least a minimal number of varicosities for subsequent analysis of their distribution. Cultures with two sensory cells and L7 in which both EPSPs decreased from one observation to the next were also discarded to remove from our morphological analysis contributions of motor or sensory neuron degeneration that may have been induced by previous manipulations. Likewise, cultures containing one sensory cell with L7 were discarded if the EPSP decreased from one observation to the next.

Electrical coupling between sensory cells was measured by recording intracellularly from both sensory cells simultaneously with two $2.5 \mathrm{M}$ $\mathrm{KCl}$ electrodes. Each sensory cell in turn was hyperpolarized to $20 \mathrm{mV}$ below resting level, the resultant deflection in the other sensory cell was recorded, and an average coupling coefficient was determined between the two (range, $0.00-0.15$ ). Sensory cells with an average coupling coefficient of $5 \%$ or greater were considered to be electrically coupled.

Dye injection and cell imaging. Fluorescent dyes 5(6)-carboxyfluorescein (Molecular Probes) and Lissamine-rhodamine B (Gurr, High Wycombe, England) were each injected into one of the two sensory cells in each culture as previously described (Glanzman et al., 1989, 1991). The former dye was used in cultures in which only one sensory cell was present with the target. Nomarski contrast and fluorescent images for each dye were taken along the major axons of L7. The original axons of L7 are linear structures, and sensory cell varicosities that overlie them are known sites of synaptic contact. Cultures were viewed on a Nikon Diaphot microscope with a Dage 66 SIT Camera. Images were processed by a Dell 310 computer with a PC Vision Plus frame grabber and subsequently stored on a Storage Dimension optical disk drive. Pictures
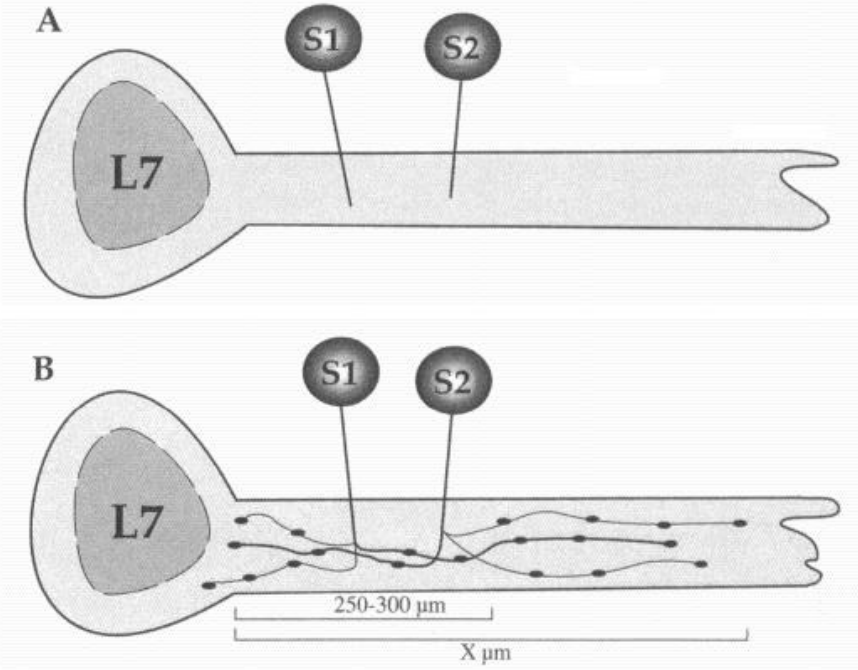

Figure 1. Placement and examination of sensory cells with the target L7 in culture. $A$, Both sensory cells $(S 1$ and $S 2)$ and $L 7$ are dissected from their respective ganglia with the proximal portion of their axonal arbor intact. The stumps of the sensory cell axons are placed on the same region of $L 7$ 's axons. $B$, Sensory cells extend neurites from their axon stumps. These new processes are mainly directed along the target cell's major axons and possess swellings or varicosities that are sites of synaptic interaction with the target (Glanzman et al., 1989). Only these varicosities were counted in our studies. For cultures viewed at one time point, we examined the proximal $250-300 \mu \mathrm{m}$ of $L 7$ 's axonal arbor. For our later studies in which cultures were viewed at two time points, the target area observed was that which contained sensory cell outgrowth at the initial viewing $(X=200-1000 \mu \mathrm{m})$. The same exact target region was observed again $1 \mathrm{~d}$ later.

from different focal planes in the same region were then superimposed for each sensory cell examined. Hard copies of the images were made with a Mitsubishi or Sony printer.

Quantification of segregation. Varicosities of each sensory cell were mapped in the region of L7's initial segment and main axons. We did not count varicosities located on minor branches of L7 since these structures do not contain unambiguous active zones (Glanzman et al., 1989). A varicosity was defined as a swelling along a sensory cell process with a diameter greater than $1.3 \mu \mathrm{m}$. Due to the thickness of sensory cell neurites and fluorescent background in some regions of the target, unambiguous swellings were often greater than twice this minimum diameter. Swellings that clearly occurred at branch points were not counted as varicosities because these structures do not appear to contain active zones on ultrastructural examination (S. Schacher, unpublished observations). Varicosities were determined on all fluorescence pictures in a blind fashion, that is, the observer did not know the experimental group (days in culture or degree of electrical coupling) to which each set of pictures belonged. In the comparison of 2-d-old to 4-d-old cultures and that of 4-d-old cultures with and without electrical coupling, only varicosities along the proximal 250-300 $\mu \mathrm{m}$ of L7's major axons were counted (Fig. 1). This region was selected because of its relative abundance of varicosities associated with active zones (Glanzman et al., 1989) and also to normalize the target area observed between experimental groups. In our studies in which the same cultures were observed on day 2 and day 3, varicosities along the length of L7's major axons containing sensory cell outgrowth on day 2 were mapped and the same exact area was reexamined $1 \mathrm{~d}$ later (Fig. 1). We expanded the area examined for these time course studies to obtain a more complete picture of varicosity dynamics along the target's axons over time. The average length of L7's axon that was examined for varicosities in these studies was not significantly different for cultures containing one or two sensory cells (531 $\pm 55.6 \mu \mathrm{m}$ for one cell and $527 \pm 42.8 \mu \mathrm{m}$ for two cells).

A map was made of varicosities on the initial segment and main axons of $\mathrm{L} 7$ by superimposing fluorescence pictures on the Nomarski image of this area. The relative positions of varicosities along the length 


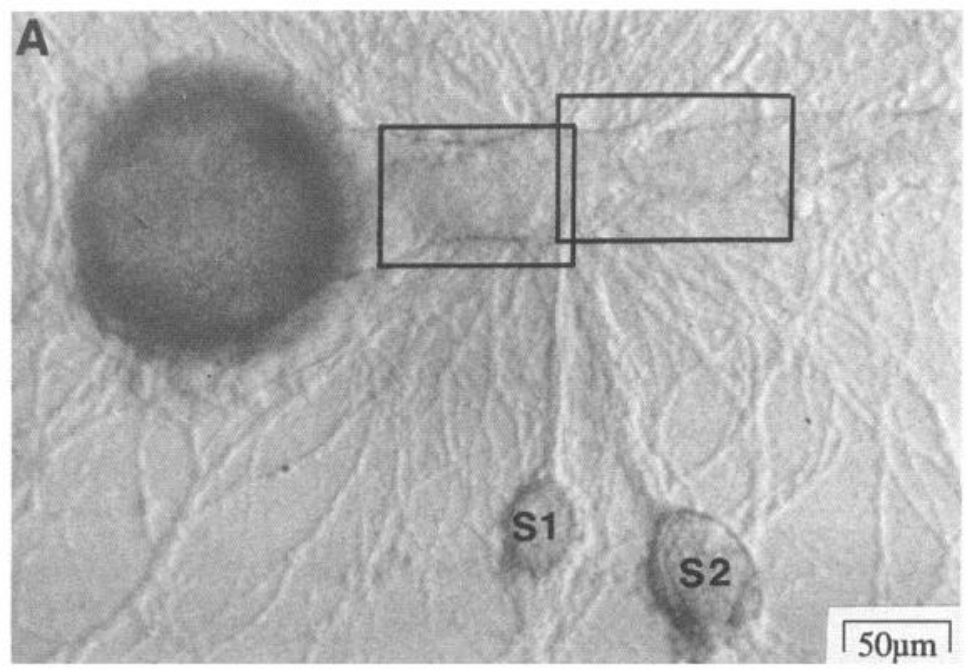

B
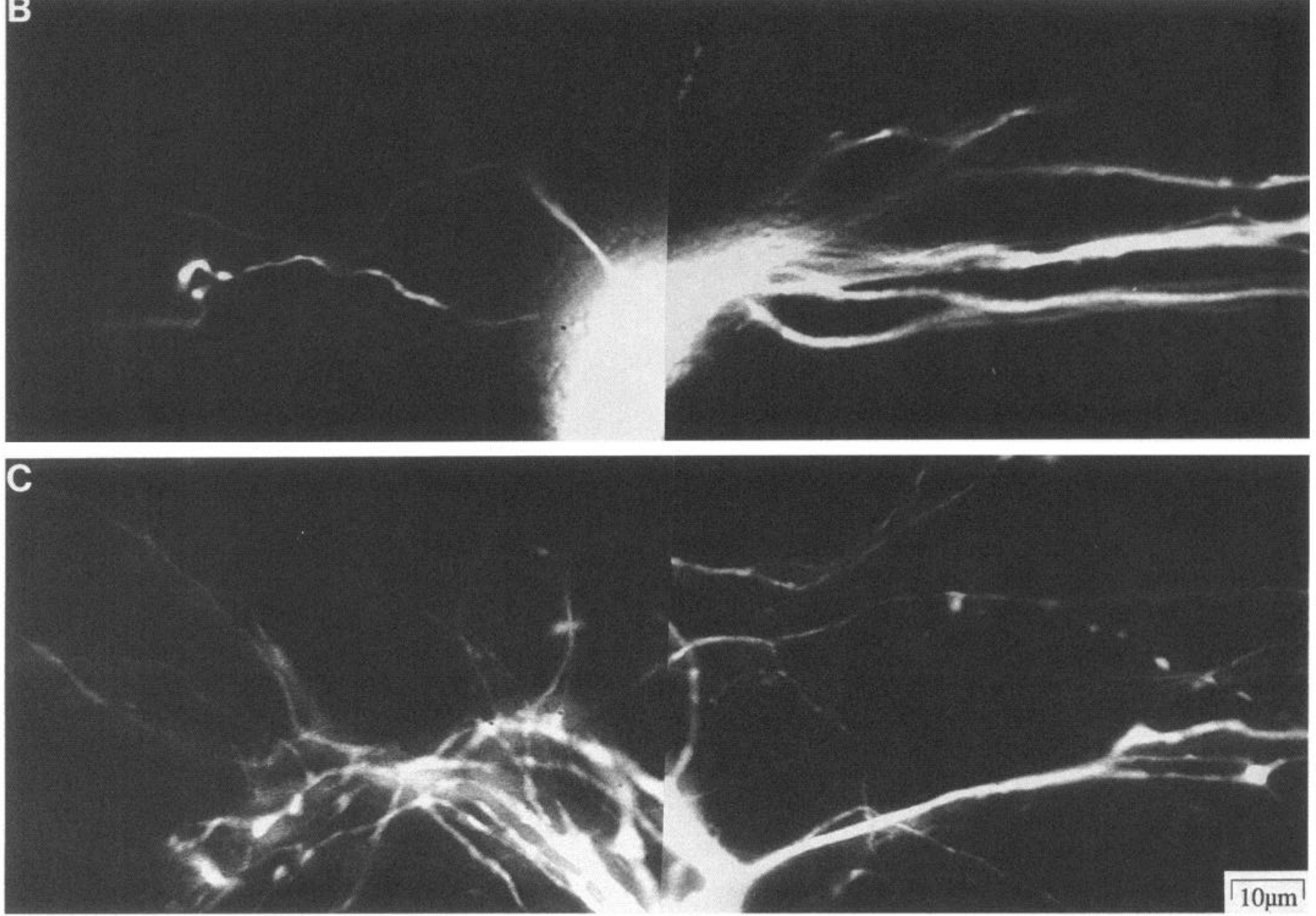

Figure 2. Segregation of sensory neuron varicosities after $4 \mathrm{~d}$ in culture. A, Nomarski contrast photomicrograph of two sensory cells ( $S 1$ and $S 2)$ plated with motor cell L7 (large cell body). No electrical coupling was observed between the sensory cells at $2 \mathrm{~d}$. $B$ and $C$ Fluorescence micrographs of processes and varicosities of each sensory cell, $S 1(B)$ and $S 2(C)$, in contact with the major axons of the motor cell (boxed areas in $A$ ). From one to four focal planes were superimposed to generate the fluorescent images in this figure as well as those of Figures 3, 5, 7, and 9. Varicosities are spatially segregated on L7's initial axon with varicosities from $S 2$ almost exclusively occupying this area. $S 1$ contributes only one cluster of varicosities. EPSPs of $5 \mathrm{mV}$ and $6 \mathrm{mV}$ were measured in L7 upon stimulation of $S 1$ and $S 2$, respectively, on day 4.

and width of the target axons were mapped onto a rectangular area to obtain Figures 6,8, and 10. The target area was divided into adjacent $50 \mu \mathrm{m}$ segments. The proximal border of the first segment was placed consistently at the boundary between L7's soma and its initial segment. The presence or absence of varicosities from each sensory cell in each of these specified $50 \mu \mathrm{m}$ segments was then scored at different times to determine the changes in the overall distribution of sensory cell varicosities along the major axons of the target.

Percentage of double occupancy was determined for cultures with two sensory cells growing on L 7 as the fraction of target segments to which 

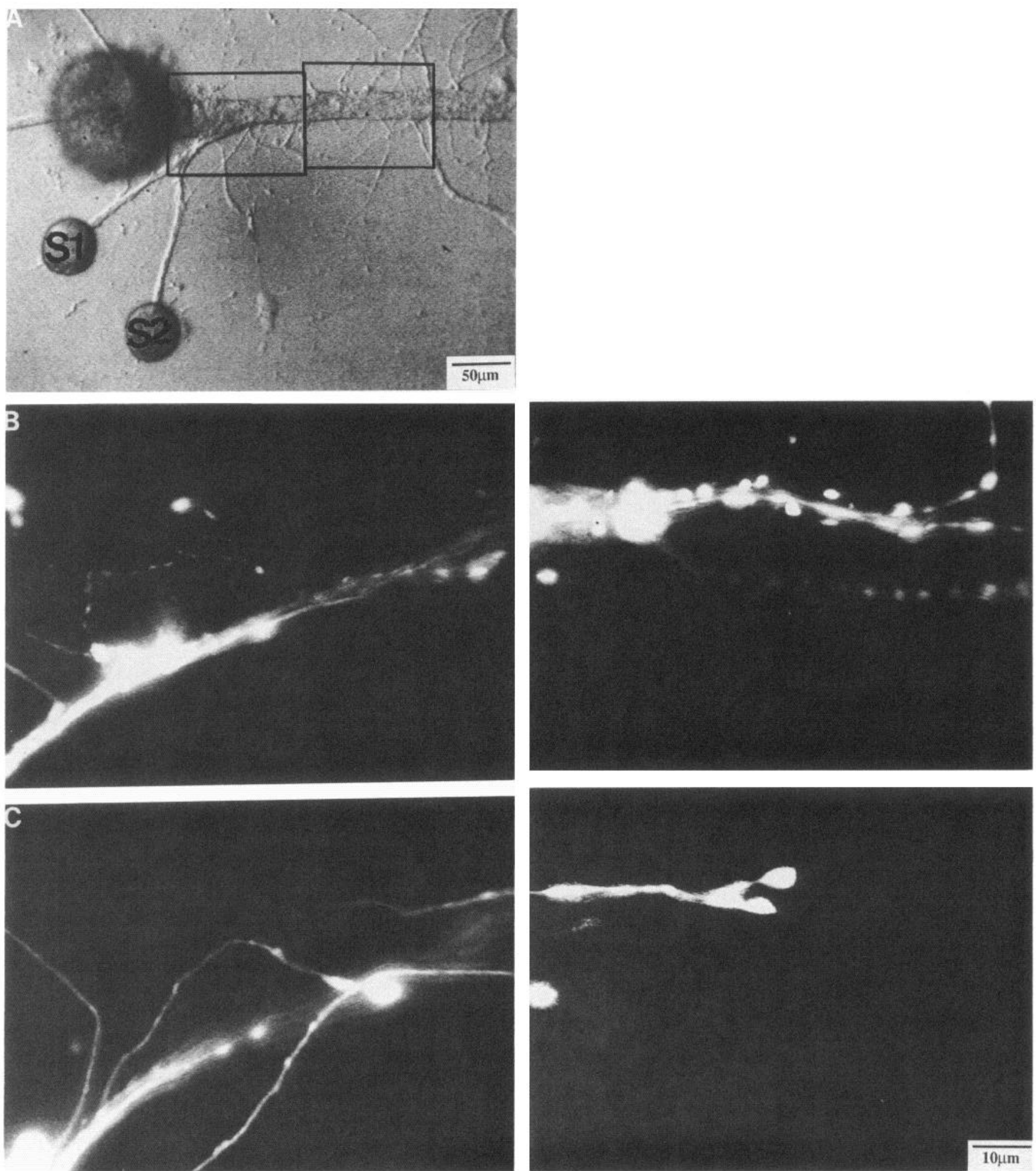

Figure 3. Sensory cell varicosities intermingle on the motor cell after $2 \mathrm{~d}$ in culture. $A$, Nomarski contrast photomicrograph of sensory cells $(S 1$ and $S 2$ ) with their axon stumps placed on the initial segment of L7's axon. The sensory cells were not electrically coupled. $B$ and $C$, Fluorescence micrographs of processes and varicosities of each sensory cell, $S I(B)$ and $S 2(C)$, in contact with the major axons of the motor cell (boxed areas in $A$ ). Varicosities from both sensory cells are present all along the initial segment of the target's axons. Stimulation of $S 1$ and $S 2$ on the second day in culture elicited EPSPs in L7 of $40 \mathrm{mV}$ and $13 \mathrm{mV}$, respectively. 


\section{DAY 2}
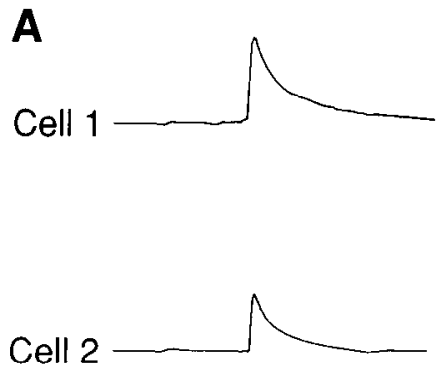

B
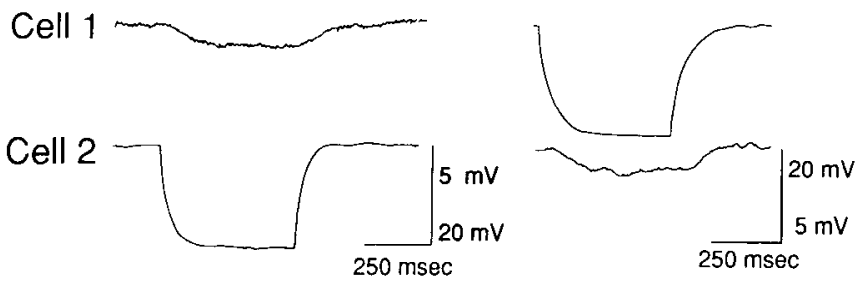

Figure 4. Sensory cells can form both chemical synapses with L7 and electrotonic connections with each other. $A$, EPSPs recorded in $\mathrm{L} 7$ by stimulating the same two sensory cells (Cell 1 and Cell 2 ) on day 2 and day 4 in culture. The amplitude of the EPSPs increased for both sensory cells over this period. The extracellular stimulus given to Cell 1 on day 4 was above threshold evoking several action potentials in the sensory cell and eliciting multiple EPSPs in L7. $B$, Measurement of electrical coupling between sensory cells after $2 \mathrm{~d}$ in culture. Hyperpolarizing current pulses in each sensory cell evoked a hyperpolarization in the other sensory cell. The average coupling coefficient was 0.05 .

both sensory cells contributed varicosities. Percentage of elimination was determined for each sensory cell as the number of target segments in which varicosities from that cell were completely eliminated from day 2 to day 3 divided by the total number of target segments originally occupied by that cell on day 2. Percentage of new occupancy was defined for each sensory cell as the number of target segments that became newly occupied by varicosities of a cell from day 2 to day 3 divided by the total number of segments that were originally unoccupied by that cell on day 2 .

In cultures with two sensory cells, another method of analysis was used to quantify segregation; for every varicosity of both sensory cells it was determined whether its closest neighbor was another varicosity from the same sensory cell or a varicosity contributed by the other sensory cell. For each culture, the percentage of segregation was then determined by calculating the fraction of all varicosities on the target with a next nearest varicosity contributed by the same sensory cell.

Analysis of data. The two-tailed Mann-Whitney test was used to compare the value of percentage of double occupancy and percentage of segregation obtained from 2-d-old cultures to that of 4-d-old cultures in cases in which sensory cells were not electrically coupled. This test was also used to compare these values in 4-d-old cultures in which sensory cells showed electrical coupling to values in 4-d-old cultures in which they did not. The significance of these comparisons was decreased by a factor of 2 ( $p$ values were doubled) because the same control group (4-d-old cultures lacking coupling) was used twice. In the comparisons of EPSPs on day 2 and increase in EPSPs from day 2 to day 4 in cultures with and without electrical coupling, a two-tailed ANOVA was used. For experiments in which the same cultures were observed on day 2 and day 3, the two-tailed Mann-Whitney test was again employed, this time to compare the values of percentage of elimination and percentage of new occupancy in cultures containing two sensory cells growing on L 7 to the values obtained from cultures in which a single sensory cell grows alone on the target. In comparing the total number of varicosities observed in cultures on day 2 to the number on day 3 , a two-tailed paired $t$ test was used. This test was also used to compare the average shortest distance between varicosities at these two time points.

\section{Results}

The segregated pattern of sensory cell varicosities emerges over time from an initial pattern of overlap

Varicosities of sensory neurons that overlie the main axons of L7 contain active zones and are thought to represent sites of synaptic interaction between these cells as in the intact nervous system (Bailey and Chen, 1983; Glanzman et al., 1989; Schacher and Montarolo, 1991). Additional support for this idea is drawn from the fact that there is a good correlation between EPSP amplitude and the number of varicositics in this target region (Glanzman et al., 1989; Schacher and Montarolo, 1991). Since sensory cells show a tendency to segregate their processes, including varicosities, to different areas of $\mathrm{L} 7$ after $4 \mathrm{~d}$ in culture (Glanzman et al., 1991), we wished to determine how this pattern forms. We tested whether this segregated pattern is present at early times in culture (day 2) and, if not, whether the pattern emerges over time.

Two sensory cells were cocultured with each $\mathrm{L} 7$ and electrical connections between them measured after $2 \mathrm{~d}$. The amplitudes of the EPSPs evoked in L7 were measured at both 2 and $4 \mathrm{~d}$. Processes of each sensory cell were visualized by intracellular injection of two different fluorescent dyes and video microscopy (Glanzman et al., 1991). We found that in cultures in which the electrical connection between the sensory cells was absent on day 2 (average coupling coefficient, $<0.05$ ), varicosities contributed by one sensory cell tended to be spatially segregated from those contributed by the other after $4 \mathrm{~d}$ in culture (Fig. 2; see also Glanzman et al., 1991). As previously reported, we observed in these cultures that large areas of the initial segment were occupied exclusively by the varicosities of only one of the sensory cells, while varicosities from the other cell appeared to be relegated to a small region of the initial segment or other areas of the target.

We next visualized the processes of sensory cells after only 2 $\mathrm{d}$ of growth (Fig. 3). The visual picture on the second day showed an intermingled pattern of varicosity distribution. Unlike the situation after $4 \mathrm{~d}$ in culture, varicosities from both sensory cells now appeared to be distributed over the same regions of the target motor cell.

In order to quantify the extent to which varicosities from each of two sensory cells were segregated on the target $\mathrm{L} 7$, we divided the initial segment of L7 (the proximal $250-300 \mu \mathrm{m}$ of L7's main axons) into $50 \mu \mathrm{m}$ segments and determined the percentage of these segments that contained varicosities from both sensory cells. In 4-d-old cultures without electrical coupling between sensory cells, the fraction of $50 \mu \mathrm{m}$ target areas containing varicosities from both sensory cells is $16.4 \pm 4.0 \%$ ( $n=9$ cultures). This low percentage reflects the visual picture of segregation seen in these cultures (Fig. 2). In 2-d-old cultures, the fraction of target segments containing varicosities from both sensory cells is $58.8 \pm 10.3 \%(n=12)$, which is significantly greater than the value obtained from 4-d-old cultures $(p<0.04$, twotailed Mann-Whitney test) and reflects the intermingled varicosity distribution seen at this earlier time (Fig. 3). These observations support the hypothesis that the pattern of segregation generated in these cultures emerges from an earlier one in which inputs overlap. 

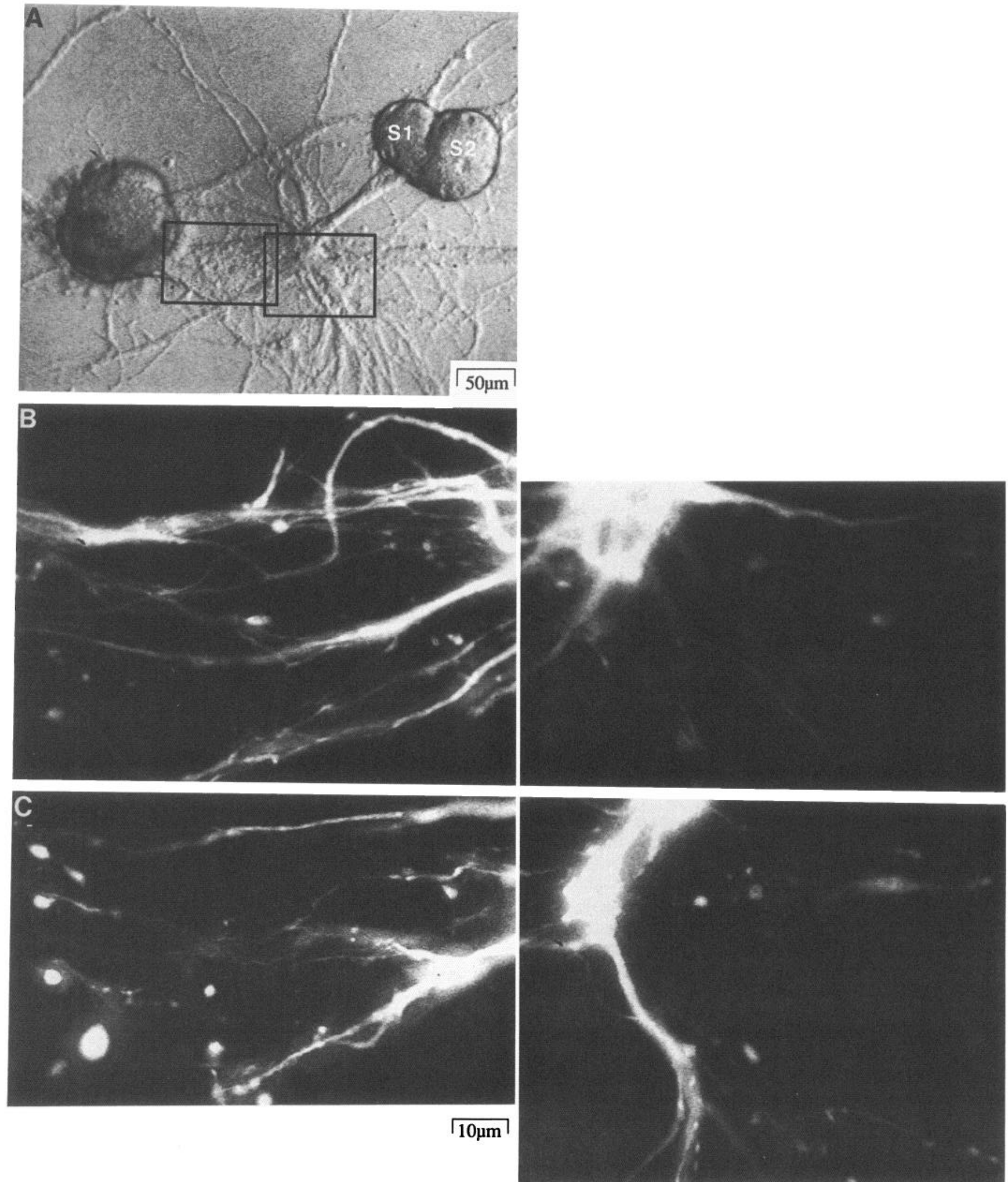

Figure 5. Sensory cell varicosities intermingle on the motor cell after $4 \mathrm{~d}$ in culture when sensory cells are electrically coupled. $A$, Nomarski contrast micrograph of two sensory cells $(S 1$ and $S 2)$ and motor cell after $4 \mathrm{~d}$ in culture. The connections between these cells are described in Figure 4. Apposition of sensory cell somas appears to facilitate the formation of electrical coupling between sensory cells. $B$ and $C$, Fluorescence micrographs of processes and varicosities of each sensory cell, $S 1(B)$ and $S 2(C)$, in contact with the major axons of the motor cell (boxed areas in $A$ ). Varicosities of both sensory cells are distributed all along the initial axons of the target. 
A

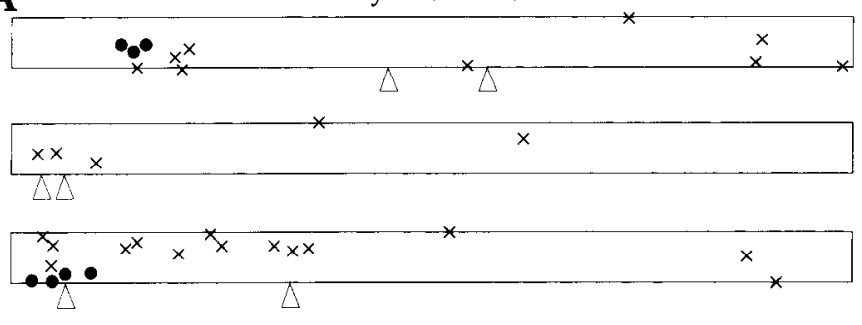

B

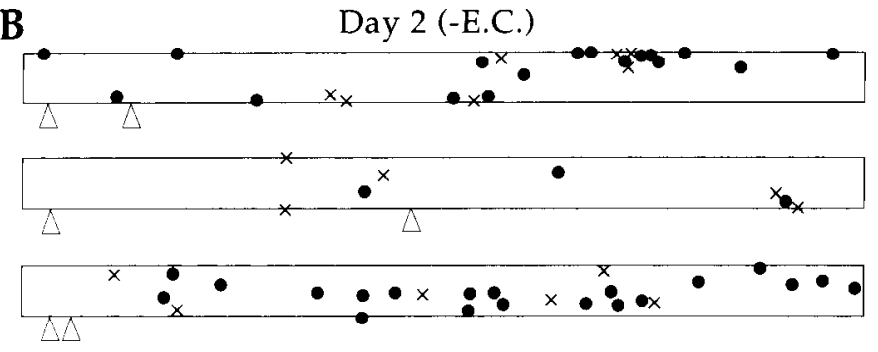

C

Day 4 (+E.C.)

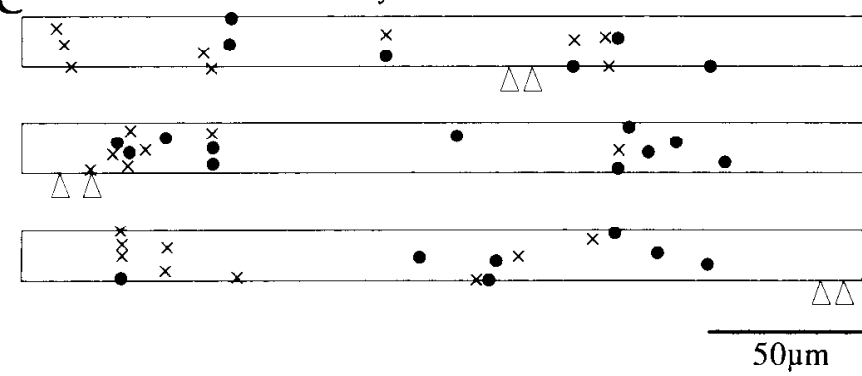

Figure 6. Distribution of sensory cell varicosities is dependent on both the time period of sensory-motor interaction and the presence of electrical connections between the sensory cells. $A$, The location of sensory varicosities on L7's initial segment for the culture shown in Figure 2 (top; S1, dots; S2, $x$ 's) with two other examples of $4 \mathrm{~d}$ cultures in which sensory cells were not electrically coupled. In these cultures, L7's initial segment is almost exclusively occupied by varicosities from only one sensory cell. $B$, The distribution of sensory cell varicosities (SI, dots; $\mathrm{S} 2, x$ 's) for the culture described in Figurc 3 (top) and two other $2 \mathrm{~d}$ cultures. In all of these cultures, sensory cells were not electrically coupled. An intermingled distribution of varicosities is observed at this earlier time. $C$, The distribution of sensory cell varicosities (S1, dots; S2, $x$ 's) for the culture described in Figure $5(t o p)$ and two other examples of $4 \mathrm{~d}$ cultures in which sensory cells are electrically coupled on day 2. Varicosities from both sensory cells are intermingled along the target's initial segment under these conditions as in B. Open arrowheads denote the location of sensory cell stumps in this figure as well as in Figures 8 and 10 .

\section{Electrical coupling between sensory cells interferes with the segregation of varicosities}

Pleural sensory cells, as other homologs isolated from the ganglia of Aplysia (Carrow and Levitan, 1989), can form electrical connections with each other in culture when plated without a motor cell (Bank and Schacher, unpublished observations). Even in the presence of $\mathrm{L} 7$, sensory cells will form electrical connections especially when the somas are plated in contact. We next wanted to see whether the presence of an electrical connection between sensory cells ( $\geq 0.05$ average coupling coefficient) affects the placement of their varicosities on the target. We therefore looked at cultures in which both sensory cells formed not only chemical synapses with $\mathrm{L} 7$ but also electrical connections with each other (Fig. 4).

When sensory cells are electrically coupled on day 2, varicosities from both sensory cells are distributed along the target in an intermingled fashion on day 4 (Fig. 5). This pattern of varicosity placement by the two sensory cells contrasts markedly with the segregated picture seen on day 4 when sensory cells lack an electrotonic connection (Fig. 2). This difference in varicosity distribution is observed despite the fact that the stumps of each sensory cell axon, the site of new outgrowth and elaboration of varicosities, are always placed in the same target region. Regardless of whether an electrical connection develops between sensory cells, the neurites of the sensory cells have equal opportunities to interact with each other on the target. In 4-dold cultures with electrical coupling between sensory cells, the fraction of target segments containing varicosities from both sensory cells is $40.6 \pm 4.1 \%(n=8)$. This value is significantly different ( $p<0.004$, two-tailed Mann-Whitney test) from that obtained from 4-d-old cultures without electrical coupling between sensory cells.

In addition to calculating the fraction of $50 \mu \mathrm{m}$ target regions occupied by varicosities from both sensory cells, segregation was also quantified through an analysis of relative varicosity placement. For every varicosity located on the target region examined, we determined whether the next closest varicosity was contributed by the same sensory cell or by the other sensory cell. In a pattern in which varicosities from different sensory cells segregate to different target regions, one would expect the fraction of varicosities with nearest neighbors contributed by the same cell to be high, approaching $100 \%$ in the limit. A more random distribution of varicosities would yield a value closer to $50 \%$. In 4-d-old cultures without sensory cell coupling, the fraction of varicosities with nearest neighbors from the same cell was $84.6 \pm 5.4 \%(n=9)$, reflecting the visual picture of a segregated pattern seen in these cultures. In 2-d-old cultures, this fraction is $57.2 \pm 8.3 \%(n=12)$, significantly less than the $4 \mathrm{~d}$ value $(p<0.04$, two-tailed Mann-Whitney test). In 4-d-old cultures with electrical coupling between sensory cells, this fraction is $46.6 \pm 5.3 \%(n=8)$; this value also is significantly less than the $4-\mathrm{d}$ value in cultures lacking this coupling $(p<0.004$, two-tailed Mann-Whitney test). Thus, we have quantified segregation by two independent methods and found that 4-d-old cultures without electrical coupling between sensory cells have a more segregated pattern of varicosity distribution than either younger cultures or cultures with sensory coupling.

Figure 6 shows maps of varicosity distributions for the three types of cultures discussed thus far; three examples of each condition are presented. Varicosities from sensory cells without electrical coupling segregate to different target areas after $4 \mathrm{~d}$ in culture (Fig. $6 A$ ) but not after only two days (Fig. $6 B$ ). By contrast, these structures do not segregate even after $4 \mathrm{~d}$ when sensory cells form an electrical connection (Fig. 6C).

The failure to segregate varicosities when cells are electrically coupled has significant consequences on the amplitudes of the EPSPs evoked in L7. At $2 \mathrm{~d}$, the amplitude of the EPSP evoked in L7 in either the presence or absence of a sensory-sensory electrical connection is not significantly different $(12.6 \pm 2.4$ $\mathrm{mV}$ for uncoupled vs $14.5 \pm 2.2 \mathrm{mV}$ for coupled; $\mathrm{df}=1,32, F$ $=0.33, p>0.55$, two-tailed ANOVA). Two days later, however, the amplitude of the sensorimotor connections in cultures with coupled cells increased by $7.5 \pm 2.1 \mathrm{mV}$, which is significantly greater than $2.4 \pm 1.3 \mathrm{mV}$, the change in the EPSP amplitude 

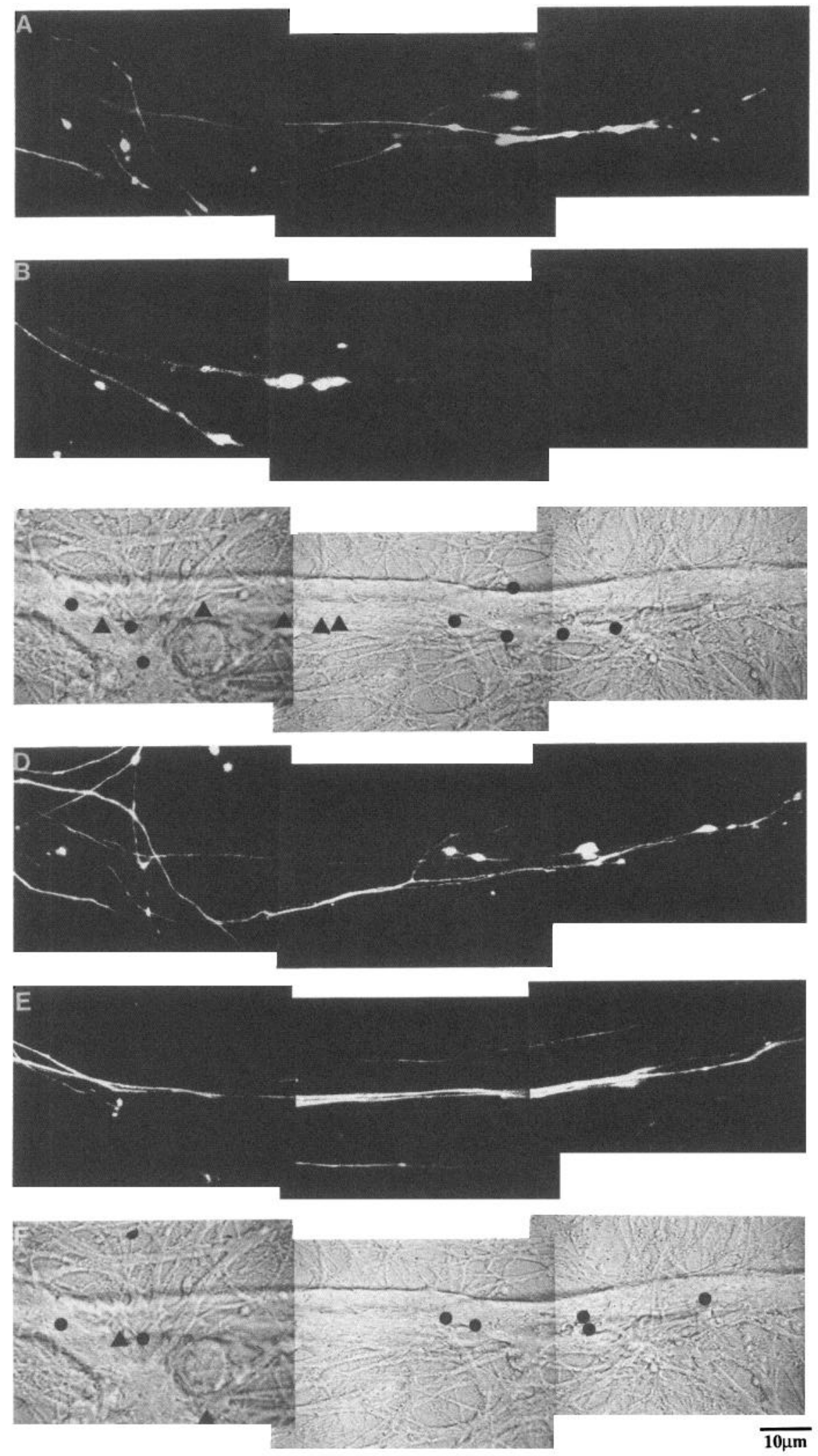

Figure 7. Segregation of sensory cell varicosities viewed over time. $A$ and $B$, Fluorescence micrographs of processes and varicosities for each sensory cell, $\mathrm{S} 1(A)$ and $\mathrm{S} 2(B)$, in contact with the major axons of L7 on day 2 in culture. The contrast of fluorescence pictures was chosen to maximize the visualization of varicosities in this figure as well as in Figure 9. $C$, Distribution of varicosities from each sensory cell on day 2 ( $\mathrm{S} 1$, circles; $\mathrm{S} 2$, triangles) superimposed on the Nomarski contrast image of a portion of L7's main axons. Varicosities from the different sensory cells are intermingled along this target area. $D$ and $E$, Fluorescent micrographs of the same sensory cells ( $A$ and $B) 24 \mathrm{hr}$ later. Many varicosities from both sensory cells that were present on day 2 have been eliminated from this region. $F$, Nomarski contrast micrograph of the same area showing the location of varicosities from each sensory cell on day 3 (S1, circles; $\mathbf{S} 2$, triangles). for uncoupled cells $(\mathrm{df}=1,32, F=4.57, p<0.05$, two-tailed ANOVA). These observations support the hypothesis that electrical coupling between presynaptic elements affects not only the morphological pattern of growth on a common target but also the efficacy of the physiological connections.

\section{Dynamics of segregation}

To characterize further the process by which varicosities from different sensory cells segregate to different target areas, we compared the change in varicosity distributions over the third day 

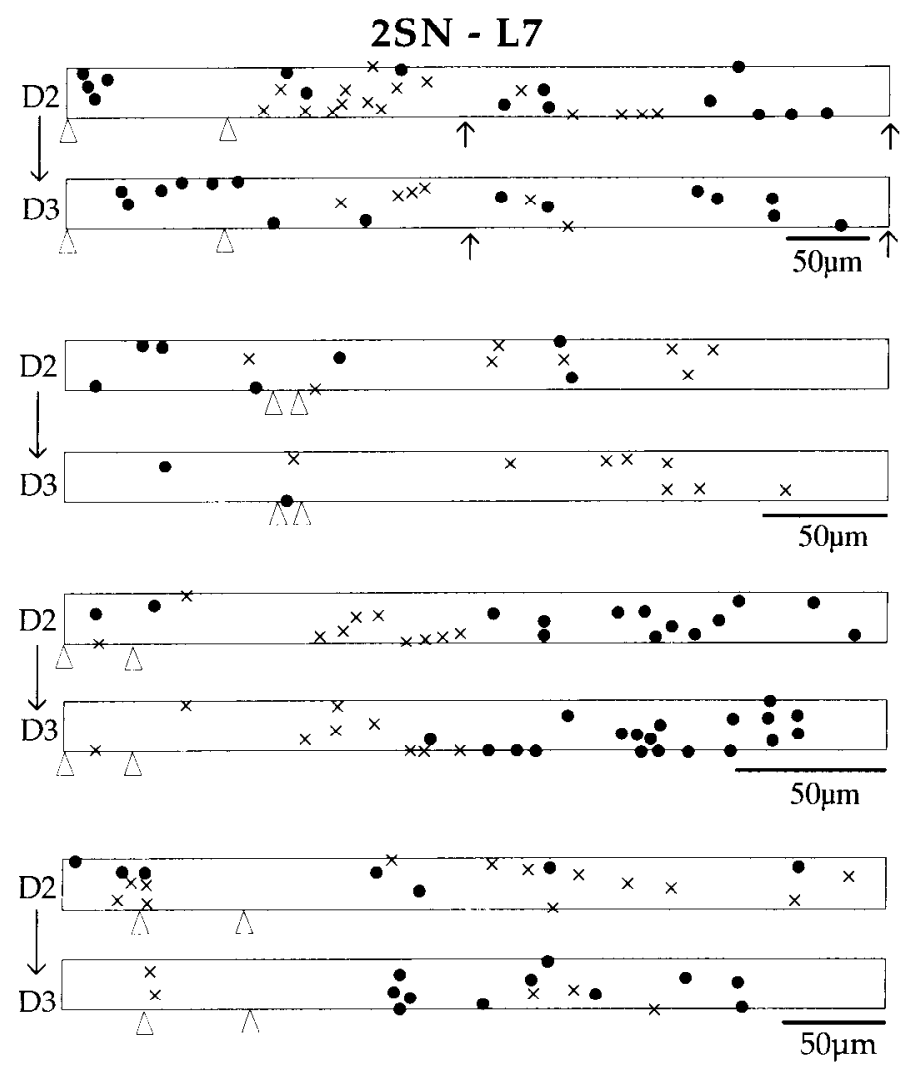

Figure 8. Varicosity distribution of two sensory neurons growing on the target viewed over time: maps of the varicosity distributions of four cultures containing two sensory cells with $\mathrm{L} 7$ at $2 \mathrm{~d}(D 2)$ and $3 \mathrm{~d}(D 3)$ in culture. The area represented by the rectangle is that region of the target's axons that contained sensory cell growth on day 2 . The first example shown (top) is that of Figure 7; arrows mark the region shown in the micrographs of that figure ( $\mathrm{S} 1$, dots; $\mathrm{S} 2, x$ 's). Open arrowheads mark the position of sensory cell axon stumps on the target. Varicosities of one or both cells tend to be lost from target regions in which these structures intermingle. New varicosities tend to form in regions occupied by older varicosities.

in culture for two sensory cells sharing a common target (Figs. 7,8 ) to that of a single sensory cell growing alone on the target (Figs. 9, 10). For each sensory cell in these studies, we determined which $50 \mu \mathrm{m}$ segments of the major axons of L7 contained varicosities from that cell at two time points, day 2 and day 3. The target region examined was the area of L7's main axons that contained sensory cell outgrowth on day 2 . The same area was reexamined $1 \mathrm{~d}$ later.

The presence of a second sensory cell increases the rate at which varicosities appear to be eliminated from previously occupied segments of the motor axon over the third day in culture. When two sensory cells are present on the target (Figs. 7, 8), varicosity distributions appear to change more radically than when a single sensory cell grows on the target (Figs. 9, 10). In cultures with two sensory cells growing on a common target ( $n$ $=20$ ), we found that $35.4 \pm 5.4 \%$ of motor axon segments that had contained varicosities of a particular sensory cell on day 2 had lost them by day 3 . In contrast, in cultures with a single sensory cell growing on the motor cell $(n=21)$, only $17.6 \pm$ $4.6 \%$ of the segments with varicosities present on day 2 had lost these structures by day 3 (Fig. 11). This difference is significant ( $p<0.05$, two-tailed Mann-Whitney test) and is consistent with the hypothesis that competing sensory cells segregate their var- icosities via a process that includes the increased elimination of these structures from previously occupied target areas. For all cultures, no significant differences are seen in the overall number of varicosities in the region examined from day 2 to day 3 ( $p>0.15$ for one cell, $p>0.5$ for two cells, two-tailed paired $t$ test). Nor were differences seen in the average nearest distance between varicosities at these two time points $(p>0.90$ for one cell, $p>0.45$ for two cells, two-tailed paired $t$ test). Thus, the elimination of varicosities from $50 \mu \mathrm{m}$ target regions cannot be accounted for by a nonspecific, general spreading of the distance between varicosities over time. The fact that total varicosity number does not change despite the elimination of varicosities from previous occupied regions suggests that varicosities are added to other target segments. These varicosity additions could occur either in areas that were formerly occupied by that cell or in new target areas.

We therefore determined the capacity of each sensory neuron to form varicosities in new motor segments over the third day. Sensory cells growing alone on L7 are more likely to elaborate varicosities into previously unoccupied areas of the motor axon than sensory cells that share the target with another sensory cell. When one sensory cell is present, the percentage of unoccupied target segments that subsequently contain varicosities on day 3 is $51.5 \pm 7.6 \%(n=20)$. This value is significantly greater $(p<$ 0.05 , two-tailed Mann-Whitney test) than $30.7 \pm 5.8 \%(n=$ $19)$, the percentage for cultures in which two sensory cells are grown on the target (Fig. 11). Thus, a restriction in the formation of varicosities in new areas of the target may he imposed by the presence of a second presynaptic cell and may contribute to the overall segregation of varicosities.

\section{Discussion}

The present report as well as previous studies (Glanzman et al., 1991) show that sensory cells of Aplysia after 4-5 d of growth in culture segregate their inputs to different areas of the target L7. These observations suggest that two presynaptic cells and a single target are all that is necessary for the segregation of presynaptic inputs in this system. Furthermore, the fact that both the sensory cells and the target L7 do not fire spontaneous action potentials in vitro argues that segregation of inputs can be established without such activity. The role of action potential activity in the development of segregation of inputs has been observed in many in vivo systems (Purves and Lichtman, 1985; Shatz, 1990a). Although spike activity does not appear to be necessary for segregation of sensory inputs on L7 in vitro, it is possible that such activity could play a role in modulating either the rate or extent of segregation. Previous work in vitro has already shown that exogenously added activity affects the magnitude of convergent inputs (Lo and Poo, 1991) as well as their ability to compete for common target cells (Nelson et al., 1989).

Similarities exist between the segregative phenomenon described in our studies and observations in vivo. The segregation of different inputs to regionally distinct areas of a common target cell has previously been reported in the intact rabbit ciliary ganglion (Forehand and Purves, 1984) in which axons from different presynaptic cells were shown to contact the same ganglion cell in areas that are spatially segregated. A second similarity is the observation that the mature segregated pattern of sensory varicosities appears to emerge over time from an initial state in which the synaptic inputs extensively overlap (for review in other systems, see Purves and Lichtman, 1985; Rakic, 1986; Shatz, 1990b). This is supported by observations that in 2-d- 


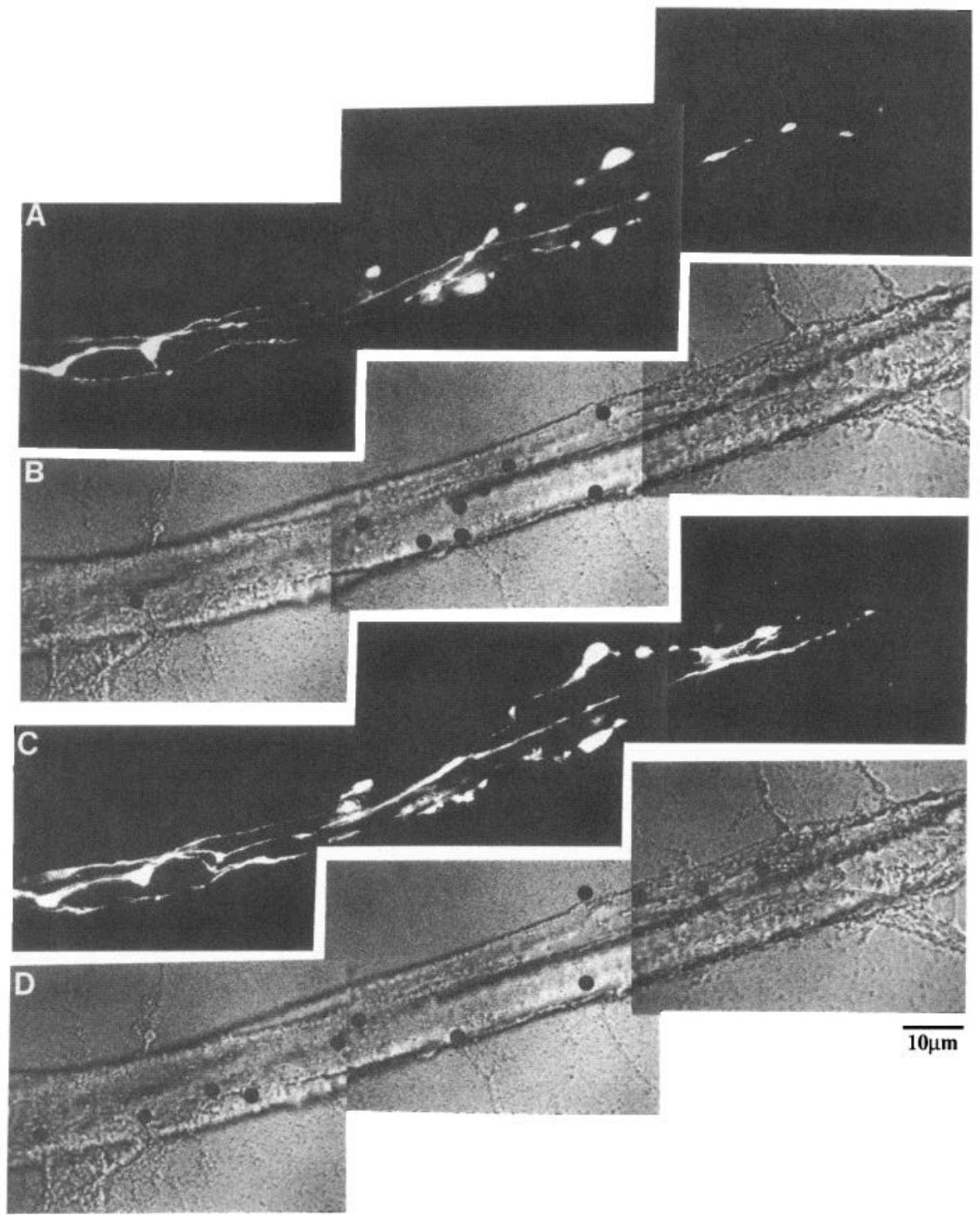

Figure 9. Varicosities of a single sensory cell growing on the target viewed over time. $A$, Fluorescence micrograph of neurites and varicosities of a sensory cell growing on L7's main axons after $2 \mathrm{~d}$ in culture. $B$, Nomarski contrast micrograph of the same area with circles marking the location of varicosities on day 2. $C$, Fluorescence micrograph of the same area of the sensory cell neurites $24 \mathrm{hr}$ later. $D$, Nomarski contrast micrograph of the same target area with circles marking the locations of varicosities on day 3 . The varicosities of a sensory cell growing alone on L7 are relatively stable over the third day in culture. old cultures varicosities from different sensory cells are not segregated on the target. Evidence both from the neuromuscular junction (Bennett and Pettigrew, 1974; Rich and Lichtman, 1989) and from the visual system (Shatz and Kirkwood, 1984; Sretavan and Shatz, 1986; Shatz, 1990b) suggests that the process of segregation involves the elimination of synaptic sites. Elimination of synapses may also play a role in the development of segregation in our system. Repeated observations made on the same cultures on the second and third day have shown the occupancy of a target area by the varicosities of a sensory cell to be more stable for a single sensory cell growing on the target than for a sensory cell that shares the target with a second sensory cell. Elimination of varicosities over the third day in culture occurs more often when a second sensory cell is present. This increased level of elimination of varicosities from previously occupied areas when two presynaptic cells interact on a common target cell during early times in culture could influence the final distribution of varicosities on the motor cell when the culture reaches a stable configuration at 4 or $5 \mathrm{~d}$ (Glanzman et al., 1989, 1991).

What do sensory cells compete for on the motor cell? It has previously been suggested that presynaptic axons compete for either a limited postsynaptic space or a limited amount of trophic factor released by the postsynaptic cell (Hubel et al., 1977; Purves, 1977; Purves and Lichtman, 1985; Rakic, 1986). Work by Rich and Lichtman (1989) has shown that the target plays an active role in the competitive interaction. In these studies on mouse muscle, it was shown that the presence of multiple axons at a single reinnervated endplate leads to the withdrawal of postsynaptic receptors associated with one of these inputs and that this withdrawal appears to be highly correlated with the subsequent elimination of the overlying inputs. In this way, one axon eventually remains exclusively at each endplate. It is possible in our system that the presence of multiple inputs in the same area of the postsynaptic target leads to a rearrangement of molecules on the target cell's surface that results in the elimination of one sensory cell's inputs in that area and the eventual segregation of inputs from different sensory cells to different target areas. Neuron-specific membrane glycoproteins have already been isolated in Aplysia with structural and functional properties similar to cell adhesion molecules, and their regulation may play a role in the structure of mature synapses (Keller and Schacher, 1990; Keller et al., 1990; Mayford et al., 1992; Bailey et al., 1992). It is attractive to think that rearrangements 

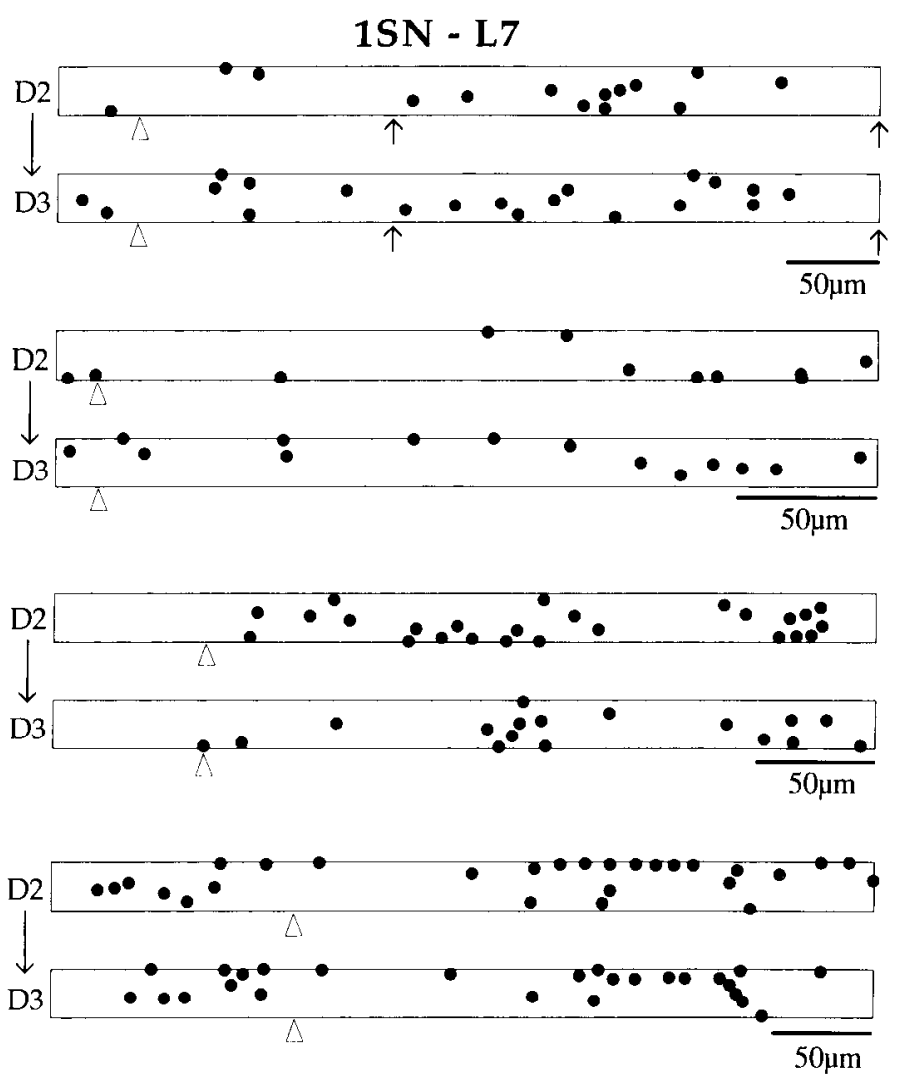

Figure 10. Distribution of varicosities for a single sensory cell growing on the target viewed over time: maps of the varicosity distribution of the culture from Figure $9(t o p)$ and three other examples of one sensory cell growing with L7 on day $2(D 2)$ and day $3(D 3)$. Arrows in the first example mark the region seen in the micrographs of Figure 9. Open arrowheads mark the position of the sensory cell stump on the target's axon. Regions of the target that contain varicosities on day 2 rarely lose these contributions over the next $24 \mathrm{hr}$. Varicosities of a sensory cell growing alone on the target appear to be more stable than those of a sensory cell that must share the target with a second sensory cell (see Fig. 8 and Results).

of these types of cell surface molecules might play a role in the segregative process in this system.

How do varicosities from one sensory cell detect those of the other sensory cell? One way that inputs from the same presynaptic cell are thought to identify an input contributed by another cell is through the presence of cell-specific activity patterns. Previous studies have suggested that the pattern of presynaptic activity affects competitive interactions such that inputs that are asynchronously active compete strongly with each other with resultant segregation while synchronous inputs do not (Hubel and Wiesel, 1965; Van Sluyters and Levitt, 1980; Stryker and Strickland, 1984; Purves and Lichtman, 1985). In our system, segregation of presynaptic inputs does not appear to require spike activity. Experiments in which presynaptic activity is added to the developing culture will help to determine whether synchronizing the activity pattern of inputs from one or both sensory cells affects spatial segregation of synaptic inputs. Aplysia sensory cells do, however, show spontaneous transmitter release in coculture with L7 (Dale and Kandel, 1990). It is possible that differences in the rate of release between the varicosities of different sensory cells could be involved in the segregative process.

Sensory cells that are electrically coupled on the second day

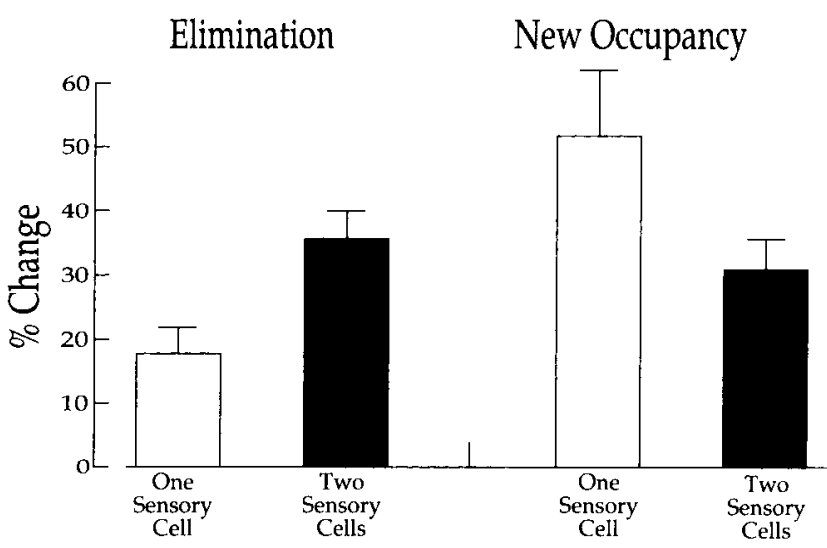

Figure 11. Percentage change over $24 \mathrm{hr}$ period in the number of old or new target regions with varicosities from each sensory cell. See Materials and Methods for definition of Elimination and New Occupancy. The bars represent the mean \pm SEM of the percentage changes in the distribution of varicosities over $24 \mathrm{hr}$ when $\mathrm{L} 7$ is cocultured with either one $(n=21)$ or two $(n=20)$ sensory cells. Varicosities of sensory cells that share the target are more likely to be eliminated from a formerly occupied area than is the case for a sensory cell growing alone on L7. The presence of a second sensory cell also makes it less likely that a sensory cell will elaborate varicosities into previously unoccupied areas of the target. See Results for additional details.

in culture fail to segregate their varicosities to different target areas after $4 \mathrm{~d}$. The intermingling of varicosities in these 4-dold cultures and their relationship to sensory cell electrical coupling could be explained in several ways. First, the intermingling of varicosities and finer processes from different sensory cells on the target might directly cause electrical coupling. We do not believe this to be the case since a similar high degree of intermingling of varicosities can be present after $2 \mathrm{~d}$ in culture without detecting any sensory-sensory coupling. A second possibility is that the electrical connection between sensory cclls forms at more proximal sites such as the cell bodies and original axons of these cells. Support for this hypothesis comes from the observation that in most, but not all, cases $(n=6$ of 9) in which sensory cells form an electrical connection, their cell bodies are directly apposed. Despite the association of sensory cell body apposition with electrical coupling, the relative placement of the two sensory cell axon stumps, the region from which new outgrowth occurs, is the same whether sensory cells develop coupling or not. It is therefore unlikely that differences in the initial plating configuration of sensory cells that are electrically coupled are responsible for the intermingled varicosity distribution seen $4 \mathrm{~d}$ later. We therefore believe that electrical coupling at more proximal sites such as the sensory soma or original axons occurs early and could be responsible for the subsequent lack of segregation of varicosities from these different cells on the target.

The consequences of even a relatively low level of electrical coupling might act to obscure the identity of each sensory cell during the initial phases of outgrowth. Electrical coupling between sensory cells might lead to an equilibration of their resting potentials. This equilibration could have the effect of equalizing the rate of spontaneous transmitter release from the two cells, since this rate has been shown to be dependent on membrane potential (Dale and Kandel, 1990). If a greater rate of spontaneous release from a varicosity conferred a competitive advantage, then an equalization of these rates between two cells would be expected to slow the segregative process. Yet another way 
that electrical connections between sensory cells could obscure their identity and disrupt segregation is by acting as conduits for the passage of small molecules. The passage of small molecules through gap junctions has been proposed as a mechanism by which the identity of a homogeneous population is established during development (Bennett et al., 1981).

In addition to differences in the distribution of varicosities, the presence of electrical coupling between sensory cells affects the efficacy of the chemical connection formed by day 4 in culture. The average increase in EPSP size from the second to fourth day was found to be significantly greater for cultures in which the sensory cells were electrically coupled. A possible explanation for this physiological difference is that the varicosity distribution for each sensory cell undergoes less extensive rearrangement with time when sensory cells form electrical connections. If fewer sites of initial synaptic contact are eliminated compared with the situation when two sensory cells lack electrical connections, then the efficacy of the connection would increase at a greater rate by the fourth day in culture.

Elimination and rearrangements of synaptic sites at mature sensorimotor connections have also been reported in this in vitro system accompanying long-term synaptic depression induced by repeated application of the neuropeptide FMRFamide (Schacher and Montarolo, 1991). These structural changes include elimination of varicosities and retraction of neurites. The sequential observations of cultures over the third day indicate that rearrangements and elimination of varicosities from previously occupied target areas arc also features that occur during the development of segregation in this system. We would like to investigate whether common mechanisms are utilized in this form of rearrangement and those changes that accompany longterm synaptic depression of stable connections. In addition, we would like to see if segregation of different sensory inputs on a common motor cell target is observed in the intact nervous system of Aplysia and to determine what role this phenomenon plays in the final pattern of connectivity. It will be of interest to see whether electrical connections between sensory cells are present in vivo and whether this presynaptic relationship is also involved in the development of proper connectivity in the animal.

\section{References}

Bailey CH, Chen M (1983) Morphological basis of long-term habituation and sensitization in Aplysia. Science 220:91-93.

Bailey CH, Chen M, Keller F, Kandel ER (1992) Serotonin-mediated endocytosis of apCAM: an early step of learning-related synaptic growth in Aplysia. Science, in press.

Bennett MR, Pettigrew AG (1974) The formation of synapses in amphibian striated muscle during development. J Physiol (Lond) 241 : 515-545.

Bennett MVL, Spray DC, Harris AL (1981) Gap junctions and development. Trends Neurosci 4:159-163.

Blackshaw SE, Nicholls JG, Parnas I (1982) Expanded receptive fields of cutaneous mechanoreceptor cells after single neurone deletion in leech central nervous system. J Physiol (Lond) 326:261-268.

Boeke J (1932) Nerve endings, motor and sensory. In: Cytology and cellular pathology of the nervous system, Vol 1 (Penfield W, ed). Reprint, pp 243-315. New York: Hafner, 1965.

Carrow GM, Levitan IB (1989) Selective formation and modulation of electrical synapses between cultured Aplysia neurons. J Neurosci 9:3657-3664

Dale N, Kandel ER (1990) Facilitatory and inhibitory transmitters modulate spontaneous transmitter release at cultured Aplysia sensorimotor synapses. J Physiol (Lond) 421:203-222.

Dale N, Schacher S, Kandel ER (1988) Long-term facilitation in Aplysia involves increase in transmitter release. Science 239:282-285.
Forehand CJ, Purves D (1984) Regional innervation of rabbit ciliary ganglion cells by the terminals of preganglionic axons. J Neurosci 4: $1-12$.

Glanzman DL, Kandel ER, Schacher S (1989) Identified target motor neuron regulates neurite outgrowth and synapse formation of Aplysia sensory neurons in vitro. Neuron 3:441-450.

Glanzman DL, Kandel ER, Schacher S (1991) Target-dependent morphological segregation of Aplysia sensory outgrowth in vitro. Neuron 7:903-913.

Gu X, Muller KJ (1990) Competitive interactions between neurons making axosomatic contacts in the leech. J Neurosci 10:3814-3822.

Hubel DH, Wiesel TN (1965) Binocular interaction in striate cortex of kittens reared with artificial squint. J Neurophysiol 28:104l-1059.

Hubel DH, Wiesel TN, LeVay S (1977) Plasticity of ocular dominance columns in the monkey striate cortex. Philos Trans R Soc Lond [Biol] 278:377-409.

Keller F, Schacher S (1990) Neuron-specific membrane glycoproteins promoting neurite fasciculation in Aplysia californica. J Cell Biol 111: 2637-2650

Keller F, Barzilai A, Grant S, Mayford M, Winicov I, Schacher S, Kandel ER (1990) Regulation by 5-HT of neural cell adhesion molecules in the nervous system of Aplysia. Soc Neurosci Abstr 16:263.6.

Lo Y, Poo M (1991) Activity-dependent synaptic compctition in vitro: heterosynaptic suppression of developing synapses. Science 254:10191022.

Mayford M, Barzilai A, Keller F, Schacher S, Kandel ER (1992) Modulation of an NCAM-related adhesion molecule with long-term synaptic plasticity in Aplysia. Science, in press.

McArdle JJ (1975) Complex end-plate potentials at the regenerating neuromuscular junction of the rat. Exp Neurol 49:629-638.

Meyer RL (1982) Tetrodotoxin blocks the formation of ocular dominance columns in goldfish. Science 218:589-591.

Montarolo PG, Kandel ER, Schacher S (1988) Long-term heterosynaptic inhibition in Aplysia. Nature 333:171-174.

Murphy RK (1986) Competition and the dynamics of axon arbor growth in the cricket. J Comp Neurol 251:100-110.

Murphy RK, Lemere CA (1984) Competition controls the growth of an identified axonal arborization. Science 224:1352-1355.

Nelson PG, Yu C, Fields RD, Neale EA (1989) Synaptic connections in vitro: modulation of number and efficacy by electrical activity. Science 244:585-587.

Purves D (1977) The formation and maintainance of synaptic connections. In: Function and formation of neural systems (Stent GS, ed), pp 21-49. Berlin: Dahlem Konferenzen.

Purves D, Lichtman JW (1985) Principles of neural development. Sunderland, MA: Sinauer.

Rakic P (1981) Development of visual centers within the primate brain depends on binocular competition before birth. Science 214:928-931.

Rakic P (1986) Mechanisms of ocular dominance segregation in the lateral geniculate nucleus: competitive elimination hypothesis. Trends Neurosci 9:11-15.

Rayport SG, Schacher S (1986) Synaptic plasticity in vitro: cell culture of identified Aplysia neurons mediating short-term habituation and sensitization. J Neurosci 6:759-763.

Redfern PA (1970) Neuromuscular transmission in new-born rats. J Physiol (Lond) 209:701-709.

Reh TA, Constantine-Paton M (1985) Eye-specific segregation requires neural activity in three-eyed Rana pipiens. J Neurosci 5:11321143.

Rich MM, Lichtman JW (1989) In vivo visualization of pre- and postsynaptic changes during synapse elimination in reinnervated mouse muscle. J Neurosci 9:1781-1805.

Schacher S (1985) Differential synapse formation and neurite outgrowth at two branches of the metacerebral cell of Aplysia in dissociated cell culture. J Neurosci 5:2028-2034.

Schacher S, Montarolo PG (1991) Target-dependent structural changes in sensory neurons of Aplysia accompany long-term heterosynaptic inhibition. Neuron 6:679-690.

Schacher S, Proshansky E (1983) Neurite regeneration by Aplysia neurons in dissociated cell culture: modulation by Aplysia hemolymph and the presence of the initial axon segment. J Neurosci 3:2403-2413.

Schacher S, Montarolo PG, Kandel FR (1990) Selective short- and long-term effects of serotonin, small cardiac peptide and tetanic stimulation on sensorimotor synapses of Aplysia in culture. $J$ Neurosci 10:3286-3294. 
Shatz CJ (1990a) Impulse activity and the patterning of connections during CNS development. Neuron 5:745-756.

Shatz CJ (1990b) Competitive interactions between retinal ganglion cells during prenatal development. J Neurobiol 21:197-211.

Shatz CJ, Kirkwood PA (1984) Prenatal development of functional connections in the cat's retinogeniculate pathway. J Neurosci 4:13781397.

Shatz CJ, Stryker MP (1988) Prenatal tetrodotoxin infusion blocks segregation of retinogeniculate afferents. Science 242:87-89.

Sretavan DW, Shatz CJ (1986) Prenatal development of retinal ganglion cell axons: segregation into eye-specific layers within the cat's lateral geniculate nucleus. J Neurosci 6:234-251.

Stryker MP, Harris WA (1986) Binocular impulse blockade prevents the formation of ocular dominance columns in cat visual cortex. $J$ Neurosci 6:2117-2133.
Stryker MP, Strickland SL (1984) Physiological segregation of ocular dominance columns depends on the pattern of afferent electrical activity. Invest Ophthalmol Vis Sci [Suppl] 25:278.

Tate K, Westerman RA (1973) Polyneuronal self-reinnervation of a slow twitch muscle (soleus) in the cat. Proc Aust Physiol Pharmacol Soc 4:174-175

Tello JF (1917) Genesis de las terminaciones nerviosas motrices y sensitivas. Trab Lab Invest Biol Univ Madrid 15:101-199.

Van Sluyters RC, Levitt FB (1980) Experimental strabismus in the kitten. J Neurophysiol 43:686-699.

Wiesel TN, Hubel DH (1965) Comparison of the effects of unilateral and bilateral eye closure on cortical unit responses in kittens. J Neurophysiol 28:1029-1040. 